\title{
PENGARUH PELANGGARAN PERATURAN PERBANKAN TERHADAP KINERJA KEUANGAN BANK DI INDONESIA
}

\author{
Yasmi Nurdin \\ yasmi.fadhli@yahoo.com \\ Habib Muhammad Shahib \\ Muhammad Gafur \\ Universitas Fajar (UNIFA) Makassar
}

\begin{abstract}
This study aims to empirically assessthe extent of theviolation of banking regulations on the financial performance of banks in Indonesia. This study used the secondary data obtained from BI and OJK and financial statements related to the violators of banking regulations in Indonesia in the range of 2010-2013. By using partially least squere approach, this research found that the violation of banking regulations does not significantly affect the financial performance of banks. Thus, It is necessary to do the advance study on the effectiveness of financial regulations that bind the banks, specifically, related to the theory and socio-economic context in Indonesia. However, this study found that the size of the violator bank (SIZE) has a positive and significant effect on the ROA and ROE abnormalities, that are commonly used as the proxies in measuring the problem of violation of financial regulations.Therefore, this result can be studied further as a one sign of the violation of financial regulation in the banking sector and can give an input to the development of accounting literature, especially related to the banking context and to the policy makers and business supervisors in Indonesia through the assessment of the effectiveness of banking regulations.
\end{abstract}

Key words: violation of banking regulations, financial performance of banks, effectiveness of banking regulations

\begin{abstract}
ABSTRAK
Penelitian ini bertujuan untuk menguji secara empiris pengaruh pelanggaran peraturan perbankan terhadap kinerja keuangan bank di Indonesia. Penelitian ini menggunakan data sekunder yang diperoleh dari BI dan OJK, serta laporan keuangan bank yang terkait bank pelanggar peraturan perbankan di Indonesia dengan rentang tahun 2010-2013. Berdasarkan hasil penelitian dengan menggunakan pendekatan partially least squere. Ditemukan fakta empiris bahwa pelanggaran peraturan perbankan tidak berpengaruh secara signifikan terhadap kinerja keuangan perbankan, sehingga perlu dilakukan kajian lebih jauh atas efektifitas peraturan keuangan yang mengikat bank-bank di Indonesia dari segi teori dan konteks sosial ekonomi Indonesia. Namun demikian, penelitian ini menemukan fakta, ukuran bank pelanggar peraturan keuangan (SIZE) memiliki pengaruh positif dan signifikan secara langsung terhadap abnormalitas ROA dan ROE yang sering menjadi proksi dalam mengukur masalah pelanggaran peraturan keuangan, sehingga dapat dikaji lebih jauh sebagai salah satu tanda terjadinya pelanggaran peraturan keuangan di perbankan. Akhirnya, penelitian ini diharapkan dapat memberi masukan kepada pengembangan literatur akuntansi khususnya yang terkait dengan konteks perbankan dan memberikan pertimbangan kepada pihak berwenang atas kebijakan dan pengontrolan bisnis melalui pengujian keefektifan peraturan perbankanyang hingga kini berlaku di Indonesia.
\end{abstract}

Kata kunci: pelanggaran peraturan perbankan, kinerja keuangan perbankan, efektifitas peraturan perbankan

\section{PENDAHULUAN}

Sebagai negara berkembang yang bertumpu pada kemampuan konsumsi pen- duduknya pertumbuhan ekonomi Indonesia condong bertumpu pada sektor perbankan melalui jasa kreditnya (BI, 2012, 
2013). Hal tersebut terkonfirmasi oleh data Bank Indonesia (BI) terkait rasio kredit perbankan terhadap PDB yang menunjukkan terjadinya peningkatan dari 20,6\% hingga $36 \%$ selama periode 1999-2013 (BI, 2012, 2013). Berdasarkan hal itu, sektor perbankan dengan jasa pengelolaan keuangan dan kreditnya semakin terbukti dari tahun ke tahun, sebagai salah satu sektor utama penopang ekonomi Indonesia.

Semakin baiknya tren perbankan sebagai katalis pertumbuhan ekonomi Indonesia akhir-akhir ini tidak dapat dilepaskan dari faktor reformasi dan perbaikan sektor keuangan Indonesia sesudah krisis ekonomi-politik 1998 (Hill, 2007; Hill dan Shiraishi, 2007; Dowling dan Yap, 2008). Pasca krisis ekonomi-politik 1998, pemerintah terus berupaya untuk membenahi seluruh sektor kehidupan berbangsa dan bernegara. Khusus untuk sektor perbankan dan keuangan, terlebih dahulu BI diperkuat melalui penerbitan UU No.7 tahun 1998 tentang perbankan, lalu pemerintah membentuk Lembaga Penjamin Simpanan (LPS) dan Badan Penyehatan Perbankan Nasional (BPPN). Selanjutnya, kehadiran UU No.23 Tahun 1999 semakin memperkuat posisi BI sebagai Bank Sentral sekaligus pengawas industri perbankan di Indonesia. Ditambah lagi dengan kebijakan memperkuat Badan Pengawas Pasar Modal dan Lembaga Keuangan (BAPEPAM-LK) untuk mengawasi pasar modal dan jasa keuangan bukan bank di Indonesia.

Selaras dengan bergulirnya waktu, khususnya pasca kehadiran Peraturan Pemerintah No.29 Tahun 1999 tentang Pembelian Saham Bank Umum. Hal ini kemudian mendorong bank-bank umum memasuki bursa pasar modal Indonesia dengan ikut serta aktif menjualbelikan sahamnya. Kondisi tersebut otomatis mendorong pemerintah untuk menghadirkan kebijakan dan peraturan baru terkait perbankan dengan harapan akan menciptakan kondisi aman, stabil, serta efisien di sistem perbankan Indonesia. Mulai dari peraturan BI hingga ke peraturan BAPEPAM-LK (seka- rang Otoritas Jasa Keuangan (OJK)). Selain kehadiran peraturan-peraturan baru tersebut sangat menyokong perbaikan sistem perbankan Indonesia setelah terpaan krisis 1998. Sesungguhnya, hal tersebut sejalan dengan Public interest theory (teori kepentingan publik) yang percaya bahwa kehadiran suatu aturan, khususnya aturan yang mengikat aktifitas ekonomi dan keuangan adalah konsekuensi dari public demand yang mengharapkan adanya pasar yang efisien. Khususnya, dalam konteks pemberian informasi ekonomi yang efisien kepada para anggota pasar (Shleifer, 2005; Alexander, 2006; Deegan, 2007; Hart, 2009; Robin, 2009; Christensen et al., 2016).

Namun, para pebisnis acap kali melakukan pelanggaran atas aturan-aturan tersebut dengan niat ingin memperoleh untung yang lebih banyak (Tyler, 1990; Qiang, 2007; Ball, 2009; Kim et al., 2011; Zeidan, 2012; Lanis dan Richardson, 2013; Shahib dan Irwandi, 2016). Sebagaimana perkara obral kredit, tidak menjelaskan bunga kredit kepada publik, melanggar acuan aman Loan to Debt Ratio (LDR) dan beragam jenis tindak pengabaian peraturan perbankan lainnya (Jackson et al., 2006; Adeyemo Kingsley, 2012; Zeidan, 2012, 2013). Hal ini juga seirama dengan pandangan positive accounting theory (Watts dan Zimmerman, 1990; Warfield et al., 1995; Peasnell et al., 2005; Deegan, 2007), yang percaya Self interest cenderung berbasis pada benefit-cost consideration. Hal yang mana akan memberikan dorongan pada manajer guna mencari peluang atau melanggar peraturan dengan tujuan untuk mengalihkan pengeluaran biaya kepatuhan menjadi laba yang lebih besar untuk perusahaan (Arjoon, 2005; Hendry, 2005; Shapiro, 2005; Chen et al., 2007; Coates IV, 2015). Isu pelanggaran peraturan di dunia bisnis, juga perbankan, telah banyak mendorong para ahli untuk mengkaji kaitan antara tindak pelanggaran peraturan terhadap kinerja keuangan perusahaan pelanggar peraturan tersebut (Baucus dan Baucus, 1997; Gunthorpe, 1997; Schnatterly, 2003; Langus dan Motta, 2007; Zeidan, 2012). Hal 
yang mana berdasar pada teori asas manfaat kepatuhan hukum (the utility of law compliance theory) (Tyler, 1990) dan teori kepentingan publik (Patten, 1991; Blacconiere dan Patten, 1994; Deegan, 2007; Barth et al., 2008) yang menerangkan bahwa aturan dilahirkan untuk menghadirkan manfaat agar prestasi kerja entitas dapat lebih baik. Sekaligus, jika peraturan dilanggar maka terdapat efek legal (jera) yang dapat menekan entitas tersebut untuk tidak kembali melakukan pelanggaran di masa depan (Black, 2008; Ball, 2009; Zeidan, 2012). Berdasarkan pemaparan tersebut, topik seputar efektifitas peraturan keuangan dan kaitannya dengan kinerja keuangan perusahaan, selalu menjadi hal yang menarik untuk ditelaah lebih jauh. Beberapa studi terdahulu yang mengkaji derajat pelanggaran aturan keuangan dengan kinerja keuangan entitas bisnis menemukan hasil yang berbeda satu dan lainnya. Baucus dan Baucus (1997) di Amerika, Langus dan Motta (2007) di Eropa dengan menggunakan perspektif teori asas manfaat kepatuhan hukum (Tyler, 1990), menemukan fakta empiris, negatifnya pengaruh tindakan pelanggaran aturan keuangan dengan kinerja keuangan entitas. Di sisi lain, Zeidan (2012) tidak medapatkan adanya hubungan empiris antara derajat tindak pelanggaran aturan keuangan dengan kinerja keuangan industri perbankan di Amerika.

Berdasarkan hasil studi terdahulu tersebut, diperoleh fakta empiris yang tidak konsisten atas pemaparan hasil kajian terkait hubungan antara pelanggaran aturan keuangan dengan tingkat kinerja keuangan perusahaan (Baucus dan Baucus, 1997; Langus dan Motta, 2007; Zeidan, 2012). Terutama, di kondisi industri dan negara yang berbeda. Jika diperhatikan dengan seksama, hal ini sekaligus mengamini legitimacy theory yang menjelaskan bahwa pengaruh legitimasi atau aturan atas entitas atau sekelompok entitas bisnis sangat bersandar pada faktor geografis, masa, dan latar sosial ekonomi di daerah operasi entitas bisnis tersebut (Deegan, 2007; Lanis dan
Richardson, 2013; Shahib dan Irwandi, 2016). Merujuk pemaparan sebelumnya, industri perbankan Indonesia menjadi menarik untuk kemudian dikaji lebih lanjut. Terutama, berhubungan dengan efektifitas peraturan perbankannya. Dikarenakan, industri perbankan Indonesia memiliki ciri yang spesifik dalam banyak hal yang kemudian membedakannya dari tipe industri lain sekaligus industri perbankan di negara lainnya.

Industri perbankan Indonesia menjadi menarik untuk dikaji lebih jauh dikarenakan memiliki banyak aturan dan diawasi oleh banyak badan supervisor, seperti BI, OJK, LPS. Entitas pengawas tersebut mempunyai aturan yang tegas demi mewujudkan operasi perbankan agar senantiasa berada di jalur yang seharusnya, namun, apakah aturan-aturan perbankan dari badan-badan pengawas tersebut telah efektif dalam memberikan efek jera kepada bank-bank yang melanggar aturan? Hal ini masih memerlukan kajian lebih jauh. Studi ini kemudian mencoba melakukan tahapan kajian lanjutan berdasar pada riset Zeidan (2012) dengan mengambil sampel bank yang terdaftar di BI dan OJK untuk menguji secara empiris bagaimana tindakan pelanggaran peraturan perbankan berefek pada kinerja keuangan bank di Indonesia.

\section{TINJAUAN TEORETIS}

\section{Teori Kepatuhan (Compliance Theory)}

Berdasar pada pandangan teori ekonomi, compliance theory (teori kepatuhan) dapat dipandang dari berbagai sisi. Neoclassical Perspective melihat peraturan di dunia bisnis adalah pengekang kebebasan untuk memperoleh keuntungan sebanyakbanyaknya (Fligstein, 1996; Sutinen dan Kuperan, 1999). Dari sisi yang lain, Watts dan Zimmerman (1986) percaya bahwa para pebisnis wajib untuk menuruti peraturan bisnis agar efisiensi pasar dapat tercapai serta agar usaha pebisnis tersebut memperoleh legitimasi dari masyarakat luas (Gray et al., 1995; Gunningham dan Rees, 1997; Deegan, 2007; Koppell, 2008; Parker dan Nielsen, 2009; MacLean dan Behnam, 2010). 
Pandangan selanjutnya datang dari Tyler (1990) yang memandang ada dua cara pandang dasar kepatuhan atas hukum atau peraturan, yaitu instrumental dan normatif. Pandangan instrumental berbasis pada cara pandang individu yang memiliki kepentingan pribadi dan reaksi atas perubahan yang berkaitan dengan perilakunya (self-interestoriented). Selanjutnya, cara pandang normatif memiliki kaitan dengan moral serta bertolak belakang dengan kepentingan individual (public-interest oriented). Seseorang akan lebih mematuhi aturan yang dianggap sesuai dan konsisten dengan norma-etika mereka. Lebih jauh, dikenal juga komitmen normatif berbasis moralitas personal (normative commitment through morality) yang bermakna mematuhi peraturan sebab kehadiran peraturan atau hukum dianggap sebagai suatu keniscayaan. Berikutnya, komitmen normatif berbasis legitimasi (normative commitment through legitimacy) yang memiliki arti bahwa tindakan patuh pada hukum dikarenakan lembaga penyusun hukum memiliki hak legitimasi dari masyarakat untuk mengeluarkan peraturan kehidupan bermasyarakat.

Lebih lanjut, Tyler (1990) berpendapat, derajat kepatuhan personal atas satu peraturan sangat berdasar pada ukuran persepsi adilnya atas lembaga penegak hukum atau peraturan. Seseorang akan condong untuk mematuhi hukum jika dia merasa hukum terlaksana dengan adil di kehidupan sehari-harinya. Selain itu, derajat kepatuhan atas hukum atau peraturan sangat bergantung pada pertimbangan cost-benefit. Hal ini selaras dengan cara pandang positive accounting theory yang memandang seseorang akan condong mengangungkan selfinterest-nya dan berlaku oportunis untuk mendapatkan keuntungan pribadi (Watts dan Zimmerman, 1986; Posner, 2001; Chung et al., 2002; Carson, 2003).

\section{Kepatuhan terhadap Peraturan Perbankan di Indonesia}

Pasca era krisis ekonomi 1998, selain memusatkan perhatiannya pada reformasi birokrasi, pemerintah Indonesia juga fokus pada pembenahan perbankan. Salah satu langkah taktis pemerintah ketika itu ialah dengan menghadirkan UU No.10 Tahun 1998 Tentang Perbankan. Undang-undang tersebut kemudian menjadi dasar bagi aturan-aturan lain terkait pengawasan aktifitas perbankan di Indonesia. Khususnya dengan menunjuk BI sebagai pelaksananya. Berdasar UU tersebut, seluruh bank yang melakukan aktivitas bisnis di Indonesia kemudian menjadi wajib untuk mematuhi semua peraturan yang dihadirkan oleh BI. Lebih lanjut, pasca diterbitkannya Peraturan Pemerintah No. 29 Tahun 1999 tentang Pembelian Saham Bank Umum. Bank-bank umum di Indonesia kemudian dibolehkan memperdagangkan sahamnya di bursa efek. Hal tersebut dengan otomatis menjadikan Bapepam (OJK, kini) sebagai institusi supervisor yang memiliki tanggung jawab untuk mengontrol bank yang memperdagangkan sahamnya di pasar saham. Berdasarkan kondisi tersebut, peraturan yang mengikat perbankan di Indonesia pun menjadi semakin banyak dan kompleks.

Merujuk pada teori dan kajian-kajian perbankan, kehadiran peraturan yang begitu banyak untuk industri perbankan merupakan suatu hal yang lazim. Dikarenakan peraturan tersebut hadir dengan dua maksud penting. Pertama, demi menjamin dan menjaga kepentingan depositor, investor, dan kreditor. Kedua, demi menjamin dan memelihara tingkat kepercayaan masyarakat luas atas industri perbankan dengan menghadirkan tindakan yang berintegritas dan menjaga reputasi industri perbankan melalui peraturan yang mengikat perbankan (Zeidan, 2012). Selain itu, bertujuan agar krisis moneter dan perbankan dapat dihindari (Barth et al., 2004; Jackson et al., 2006) sebab daya rusak krisis moneter begitu hebat layaknya domino effect yang dengan mudah dapat menghancurkan pondasipondasi penopang perekonomian satu negara. Atas dasar tersebut, Pemerintah Indonesia lalu mendorong seluruh bank yang beraktivitas bisnis di Indonesia untuk 
patuh pada peraturan perbankan, baik peraturan BI atau OJK agar efektifitas dan efisiensi di industri perbankan dapat tercapai demi memperkuat perekonomian nasional.

\section{Pelanggaran Peraturan Perbankan}

Tindakan atau perkara pelanggaran peraturan keuangan atau perbankan pada dasarnya cenderung memiliki kesamaan di banyak negara di dunia termasuk Indonesia, khususnya dalam konteks landasan filosofis yang mendasari tindakan terebut yakni berlandaskan dorongan self-interst dan sikap oportunis (Watts dan Zimmerman, 1986; Jackson et al., 2006; Benmelech dan Moskowitz, 2010; Rezaee dan Riley, 2010; Zeidan, 2012, 2013). Namun, perkara pelanggaran ini sukar dibuktikan apabila tidak menggunakan teknik pemeriksaan atau audit secara terperinci terhadap suatu entitas bank (Firth et al., 2005; Salehi dan Azary, 2009; Rezaee dan Riley, 2010). Oleh karena itu, kebutuhan akan hadirnya institusi pengawas yang khusus bekerja untuk mengawasi dan menghukum bank yang melakukan tindak pelanggaran menjadi wajib. Agar para stakeholder di industri perbankan dapat terhindar dari tindakan pengambilan keputusan bisnis dengan basis informasi yang menyesatkan serta tidak menjadi korban dari tindak kejahatan perbankan.

Di Indonesia terdapat beberapa instansi yang memiliki fungsi pengawasan dan penegakan hukuman atas aktifitas perbankan, yakni Bank Indonesia (BI), Otoritas Jasa Keuangan (OJK) yang sebelumnya bernama Badan Pengawas Pasar Modal-Lembaga Keuangan (BAPEPAM-LK) dan Lembaga Penjamin Simpanan (LPS). Sebagai contoh, BI dan OJK memiliki agenda rutin tahunan menginformasikan kepada khalayak luas atas kinerja bank-bank yang beroperasi di Indonesia serta turut memberi sanksi kepada bank yang melakukan tindak kecurangan dan pelanggaran aturan perbankan guna menghadirkan efek jera kepada bankbank pelanggar aturan tersebut. Jika di- perhatikan secara seksama, hal ini sejalan dengan pandangan Williams (2007) yang percaya praktik kecurangan atau perbuatan melawan hukum cenderung berefek buruk kepada publik. Juga akan menyebabkan melemahnya legitimasi sosial satu entitas di tengah-tengah khalayak umum (Ball, 2009; MacLean dan Behnam, 2010; Mishina et al., 2010; Lamin dan Zaheer, 2012; Lanis dan Richardson, 2013) sehingga tindakan kecurangan dan pelanggaran harus dapat dihindari dan dimusnahkan.

\section{Pengukuran Kinerja Keuangan Perbankan}

Informasi keuangan seringkali disimbolkan atau didasarkan pada berbagai rasiorasio akuntansi. Rasio-rasio ini kemudian dipercaya luas oleh para stakeholder sebagai hal utama lagi bermanfaat yang harus digunakan dalam proses pengambilan keputusan bsinis dan ekonomi. Berdasar alasan itu juga, BI dan Bapepam (OJK) sebagai institusi yang berfokus dalam hal pengontrolan perbankan kemudian mendorong terwujudnya informasi keuangan yang berkualitas berbasis pada karekteristik kualitatif informasi akuntansi yakni understandability, relevant, reliability, dan comparability (IAI, 2013) agar dapat dimanfaatkan sebagai acuan pengambilan keputusan para pebisnis.

Lebih lanjut, berbicara tentang pengukuran kinerja keuangan bank. Ditemukan fakta pada beberapa studi dan praktik yang telah dilakukan di industri perbankan termasuk institut pengawasnya di banyak negara, ukuran atau proksi akuntansi seperti ROA (return on asset) dan ROE (return on equity) umumnya digunakan untuk menilai kinerja keuangan perbankan secara langsung maupun tidak langsung (Rivard dan Thomas, 1997; Palepu et al., 2010; Zeidan, 2012). Dikarenakan indikator ROA dan ROE dianggap mampu menggambarkan kondisi bank terkait kemampuannya untuk menghasilkan returns atas aset yang dikuasai oleh bank. Sekaligus, proksi ROA dan ROE dipercaya mampu menggambarkan profitabilitas dari proyek-proyek investasi perban- 
kan (Simpson dan Kohers, 2002; Palepu et al., 2010). Lebih jauh, ROA dan ROE juga acap kali digunakan sebagai acuan dasar untuk menilai efektifitas aturan yang mengikat perusahaan dan perbankan (Baucus dan Baucus, 1997; Zeidan, 2012; Lanis dan Richardson, 2013; Shahib dan Irwandi, 2016).

Dalam konteks Indonesia, BI dengan Peraturan Bank Indonesia Nomor 6/10/ PBI/2004 tanggal 12 April 2004 dan Surat Edaran Bank Indonesia Nomor 6/23/DPNP 31 Mei 2004 mengatur derajat kesehatan bank umum yang beroperasi di Indonesia. Penilaian derajat kesehatan bank tersebut berdasar pada kualitas aset, ukuran permodalan, rentabilitas, likuiditas, manajemen, dan sensitivitas terhadap risiko pasar.

Peraturan tersebut kemudian berkonsekuensi setiap tahunnya BI wajib melaporkan kinerja perbankan di Indonesia secara komprehensif pada Laporan Tahunan Kinerja Ekonomi Indonesia. Proksi yang menggambarkan tingkat kesehatan perbankan seperti menghitung risiko kredit perbankan dengan berbasis ukuran NPL (Non Performing Loan), profitabilitas perbankan diproksikan dengan ROA dan NIM (Net Interest Margin), derajat kemampuan permodalan Bank diwakili dengan rasio CAR (Capital Adequacy Ratio), ukuran efisiensi perbankan diwakili rasio BOPO (Biaya Operasional-Pendapatan Operasional), dan likuiditas perbankan dengan rasio LDR (Loan to Debt ratio), menjadi ukuran-ukuran yang umum digunakan dalam laporan tersebut (BI, 2013).

\section{Pelanggaran Peraturan Perbankan dan Kinerja Keuangan Bank}

Studi terdahulu yang mengkaji hubungan antara pelanggaran aturan keuangan terhadap kinerja keuangan perusahaan, termasuk bank, menemukan fakta empiris yang cenderung tidak konsisten. Baucus dan Baucus (1997) yang melakukan riset atas 300 perusahaan terindeks Fortune yang melanggar aturan dalam rentang lima tahun, mendapatkan fakta empiris yang menggambarkan pelanggaran peraturan memiliki pengaruh negatif atas kinerja jangka panjang perusahaan. Selanjutnya, Langus dan Motta (2007) menggunakan abnormal market returns to the stock price sebagai proksi pengukur kinerja perusahaan menemukan fakta empiris entitas bisnis eropa yang melanggar aturan juga condong mendapatkan negative returns. Namun menariknya, Zeidan (2012) yang khusus melakukan riset atas pengaruh pelanggaran aturan perbankan pada kinerja keuangan bank-bank di Amerika mendapatkan simpulan tidak adanya pengaruh tindak pelanggaran peraturan perbankan atas kinerja keuangan bank-bank di Amerika.

Berdasarkan ketidak konsistenan hasil studi-studi sebelumnya, maka kajian artikel ini yang mencoba mengaitkan dan menguji kembali pelanggaran aturan perbankan beserta hubungannya dengan kinerja keuangan bank dalam ruang dan waktu yang berbeda tetap menarik untuk dikaji lebih jauh. Dikarenakan industri perbankan dengan karekteristik banyaknya aturan yang melingkupinya dan banyaknya institusi yang mengawasinya adalah satu fenomena unik. Khususnya, dalam dimensi ekonomi suatu negara, industri perbankan memiliki pengaruh yang begitu penting, termasuk juga di Indonesia yang menjadi case study riset ini. Lebih jauh, studi ini juga mencoba menilai seberapa efektif peraturan perbankan yang selama ini telah diterapkan di Indonesia.

Selanjutnya, dalam rangka menganalisis pengaruh pelanggaran peraturan perbankan terhadap derajat kinerja keuangan bank-bank di Indonesia. Berangkat dari pembahasan teori dan penjelasan yang telah diuraikan sebelumnya maka kerangka pemikiran untuk penelitian ini digambarkan seperti gambar 1 .

\section{Pengembangan Hipotesis \\ Pengaruh Pelanggaran Peraturan Perban- kan terhadap Kinerja Keuangan Bank}

Riset-riset yang mengkaji tindakan pelanggaran hukum atau peraturan seperti kasus fraud dalam konteks bisnis, umumnya mendapatkan fakta empiris bahwa entitas 
yang diindikasikan melakukan fraud, kinerja keuangannya cenderung melemah dikare- nakan oleh hukuman yang didapatkannya (Schnatterly, 2003; Rezaee dan Riley, 2010).

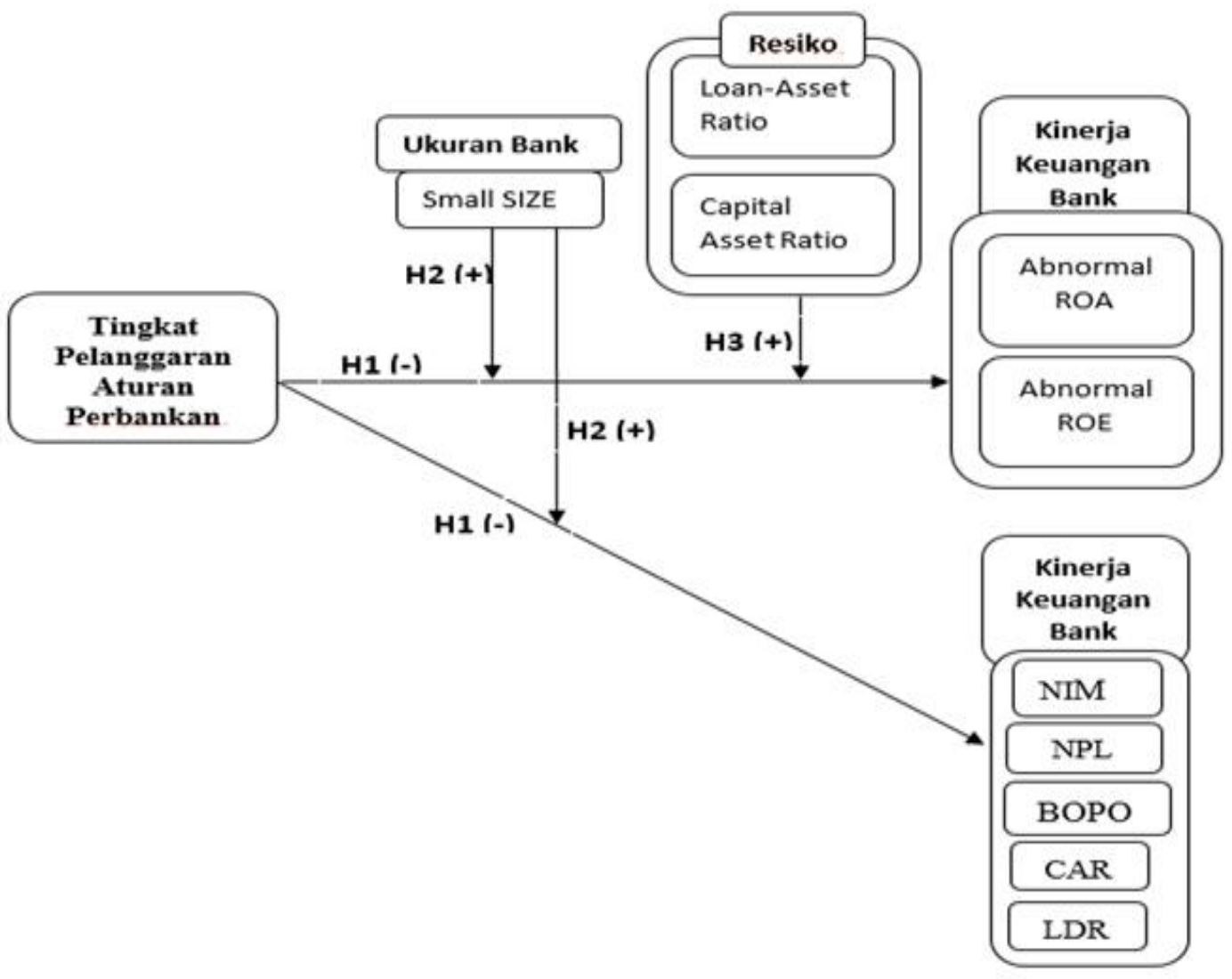

Gambar 1

Sumber: Dikembangkan untuk penelitian

Rerangka Pemikiran Penelitian

Merujuk argumen tersebut, serta beberapa hasil studi terdahulu yang mendapatkan fenomena yang menunjukkan adanya pengaruh negatif pelanggaran peraturan keuangan terhadap kinerja keuangan perusahaan (Baucus dan Baucus, 1997; Langus dan Motta, 2007). Maka hipotesis yang diuji pada penelitian ini dengan menggunakan proksi ROA dan ROE serta Rasio lain yang juga digunakan Bank Indonesia sebagai indikator pengukuran kinerja keuangan bank seperti NPL (Non Performing Loan), NIM (Net Interest Margin), CAR (Capital Adequacy Ratio), BOPO (Biaya Operasional-Pendapatan Operasional), dan LDR (Loan to Debt ratio) (BI, 2012, 2013) adalah:

$\mathrm{H}_{1}$ : Pelanggaran peraturan perbankan berdampak negatif terhadap kinerja keuangan bank.
Hubungan Ukuran Bank denganAkibat Pelanggaran Aturan Perbankan di Indonesia

Di banyak literatur yang mengkaji corporate financial performance bersama corporate social performance, ukuran perusahaan atau entitas bisnis umumnya diproksikan dengan ukuran aset total dan umumnya diasumsikan ukuran perusahaan cenderung memiliki pengaruh yang signifikan kepada total kinerja perusahaan (Lanis dan Richardson, 2013). Selanjutnya, Zeidan (2012) menambahkan, ukuran perusahaan khususnya dalam penelitian perbankan cenderung memiliki moderating effect terkait dengan hubungan derajat pelanggaran peraturan perbankan dan kinerja keuangan bank. Dikarenakan, kecenderungan bisnis yang se makin besar lebih mampu untuk me- 
nyelesaikan masalah hukum serta denda yang didapatkannya tanpa memberi pengaruh terhadap kinerja keuangan entitas secara keseluruhan. Atas dasar penjelasan tersebut, hipotesis yang diuji dengan menggunakan indikator Aset total sebagai proksi ukuran bank adalah:

$\mathrm{H}_{2}$ : Semakin kecil ukuran bank, kinerja keuangannya semakin terpengaruh dengan tindakan pelanggaran peraturan perbankan.

\section{HubunganKondisi Bank Berisiko dengan Efek Pelanggaran Peraturan Perbankan}

Di dalam kajian ekonomi-bisnis, jika dikontekskan dengan pelanggaran peraturan bisnis, semakin berisiko suatu bisnis yang dijalankan oleh perusahaan, perusahaan tersebut cenderung sensitif terhadap dampak dari peraturan yang mengatur aktivitas bisnisnya (Zeidan, 2012). Berbicara kaitannya dengan risiko bank, terdapat dua proksi yang sering digunakan untuk mengukur risiko bank, yakni Capital to Asset Ratio dan Loan to Asset Ratio.

Indikator ini menggambarkan semakin besar nilai Capital to Asset Ratio dan Loan to Asset Ratio maka semakin kecil atau rendah risiko bank, pun juga sebaliknya (Zeidan, 2012). Berdasar hal itu, hipotesis yang diuji menggunakan dua proksi tersebut adalah:

$\mathrm{H}_{3}$ : Semakin tinggi risiko suatu bank, maka pelanggaran peraturan perbankan cencenderung memengaruhi kinerja keuangannya.

\section{METODE PENELITIAN}

Artikel ini menggunakan pendekatan riset eksplanatory-quantitative study dengan tujuan mendapatkan kejelasan empiris atas fenomena, sekaligus berupaya untuk melakukan verifikasi jawaban atas pertanyaan dan hipotesis penelitian yang menghubungkan variabel independen dengan variabel dependen berbasis analisis statistik. Data penelitian ini adalah data sekunder yang diperoleh dari Bank Indonesia (BI) serta Otoritas Jasa Keuangan (OJK).

\section{Populasi dan Sampel Penelitian}

Studi ini memilih populasi yaitu bankbank yang terdaftar di BI dalam rentang tahun 2010-2013. Harapannya, populasi dan rentang tahun tersebut dapat mendeskripsikan situasisetelah krisis ekonomi-moneter 1998 yang relatif baru. Khususnya, setelah era reformasi industri perbankan dan telah lengkapnya kehadiraninstitusi pengawas perbankan Indonesia (BI, OJK, LPS). Sehingga, kondisi tersebut dianggap aktual untuk konteks industri perbankan Indonesia. Kemudian, bank-bank yang menjadi sampel dalam riset ini yaitu bank-bank yang melakukan pelanggaran peraturan keuangan perbankan berdasar pada penilaian BI dan OJK dalam rentang 2010-2013.

\section{Variabel Penelitian \\ Variabel Dependen-Kinerja Keuangan}

Merujuk pemaparan sebelumnya, ROA dan ROE menjadi indikator yang mengukur kinerja keuangan bank-bank. Dalam penelitian ini, untuk mendapatkan dampak pelanggaran peraturan perbankan terhadap kinerja bank-bank. Diadopsilah persamaan pengembangan ROA dan ROE dari Zeidan (2012, 2013), dengan membandingkan antara kinerja bank pelanggar dengan bank-bank yang tidak melanggar peratirann perouksal - m yang digambarkan dalam persamaan herikut:

$$
\begin{aligned}
& \text { Keterangan: } \\
& \mathrm{AbnROA}_{\mathrm{ij}}=\text { Abnormal ROA Bank } i \text { di waktuj } \\
& R O A_{i j} \quad=R O A \text { Bank } i \text { di waktuj } \\
& \text { AveCompROA } A_{i j} \quad=\text { Rata-rata ROA dari Bank kompetitor } \\
& \text { di waktuj } \\
& =0,1,2, \ldots \text { masa setelah terjadinya } \\
& \text { pelanggaran aturan perbankan } \\
& \begin{aligned}
& A b n R \\
& \text { Keterangan: }
\end{aligned} \\
& \text { AbnROE } E_{i j} \quad=\text { Abnormal ROE Bank i di waktu } j \\
& R O E_{i j} \quad=R O E \text { Bank } i \text { di wakiu } j \\
& \text { AveContpROL } L_{i j}=\text { Rata-rata ROL dari Bank } \\
& \text { kompetitor di waktu } j \\
& \text { J }
\end{aligned}
$$$$
A b n R O A_{i j}=R O A_{i j}-\text { AveCompROA } i j i j
$$ 


\section{Variabel Dependen-Kinerja Keuangan Versi BI}

Berdasarkan Peraturan BI Nomor 6/10/ PBI/2004 per tanggal 12 April 2004 tentang sistem penilaian tingkat kesehatan bank umum. Juga berdasar pada ukuran kinerja perbankan yang diungkapkan pada Laporan Tahunan Ekonomi Indonesia (BI, 2013) Berikut indikator-indikator kesehatan atau kinerja keuangan bank versi BI:

\section{NIM (Net Interest Margin)}

NIM adalah gambaran rasio pendapatan bunga bersih terhadap rata-rata aset produktif bank. Pendapatan bunga dikurangi beban bunga itulah pendapatan bunga bersih. Sedangkan yanng dimaksud aset produktif yaitu aset yang menghasilkan bunga (Peraturan Bank Indonesia nomor 7/2/ PBI/2005). Sebagaimana diketahui bunga adalah pendapatan utama dari bank, oleh karena itu, bank harus berupaya menjaga kualitas aset produktifnya. Rasio dari NIM kemudian diukur dalam persamaan berikut:

$$
N I M=\frac{\text { Pendapatan Bunga Bersih }}{\text { Rata }- \text { rata Asset Produktif }}
$$

\section{NPL (Non Performing Loan)}

Rasio NPL menggambarkan besaran risiko kredit, semakin kecil nilai NPL semakin kecil pula risiko kredit yang mungkin ditanggung bank. Umumnya, nilai NPL yang dianggap baik adalah bernilai dibawah $5 \%$. Jika NPL suatu bank cenderung tinggi maka potensi kerugian bank juga cenderung meningkat. Rasio dari NPL kemudian diukur dalam persamaan berikut:

$$
N P L=\frac{\text { Kredit yang bermasalah }}{\text { Kredit yang disalurkan }}
$$

\section{BOPO (Biaya Operasional-Pendapatan Operasional)}

Rasio yang mengukur dampak biaya operasi terhadap pendapatan operasi bank dikenal dengan BOPO. Biaya operasi dalam konteks perbankan adalah biaya yang dikeluarkan dalam rangka menjalankan aktivitas usaha utama suatu bank, diketahuai antara lain biaya bunga, biaya tenaga kerja, biaya pemasaran, dan biaya operasi lainnya. Sedangakan, pendapatan operasi adalah sumber pendapatan yang diperoleh dari kredit serta pendapatan operasi perbankan lainnya. Semakin besar nilai BOPO maka menggambarkan semakin tidak efisien bank tersebut. Sebaliknya, semakin kecil nilai BOPO menggambarkan semakin efisien aktivitas usaha suatu bank. rasio BOPO-nya yang dianggap sehat adalah kurang uarr ${ }^{*}{ }^{1}$ (satu) $(100 \%)$. BOPO kemudian diưkur dengan persamaan berikut:

$$
B O P O=\frac{\text { Total Beban Operasional }}{\text { Total Pendapatan operasional }}
$$

\section{CAR (Capital Adequacy Ratio)}

CAR dipercaya sebagai acuan ukuran untuk menilai ekspansi suatu bank dalam bidang perkreditan. Rasio CAR mengukur perbandingan antara modal dengan aset tertimbang menurut risiko (ATMR) yang dimiliki bank. Di Indonesia, perhitungan CAR dikenal dalam terma Bank Indonesia sebagai Kewajiban Penyediaan Modal Minimum Bank (KPMM) dan perhitungannya tidaklah sederhana dikarenakan semua terikat dengan peraturan bank Indonesia. Dalam penelitian ini LAk? diukur dengan persamaan berikut:

$$
C A R=\frac{\text { Moddal }}{\text { Aset tertimbang mmenurut risiko }}
$$

\section{LDR (Loan to Deposit Ratio)}

Rasio yang sering digunakan untuk mengukur kemampuan bank dalam memenuhi kewajiban keuangannya dikenal sebagai LDR. Menghitung LDR umumnya menggunakan persamaan berikut:

$$
L D R=\frac{\text { Kredit yang disalurkan }}{\text { Dana Pihak ke tiga }}
$$

\section{Variabel Independen Pelanggaran Peraturan Perbankan(Violation)}

Selanjutnya, variabel independen yang digunakan dalam penelitian ini untuk mengukur derajat pelanggaran peraturan perbankan, yang ditemukan oleh pengawas perbankan yakni BI dan OJK, akan meng- 
gunakan proksi skor berbasis hukuman denda yang dijatuhkan oleh BI dan OJK pada bank pelanggar aturan. Berdasar pada asumsi, semakin besar denda yang diberikan maka bank tersebut dipercaya melakukan pelanggaran yang semakin berat.

Hal ini juga dilakukan dengan harapan dapat memberikan kebaruan dalam penelitian ini agar berbeda dengan penelitian sebelumnya yang meneliti tema yang sama (Zeidan, 2012, 2013; Shahib dan Irwandi, 2016). Berikut skema rentang skor denda (tabel 1) yang akan digunakan di penelitian ini:

\section{Tabel 1}

Skema rentang denda(Violation) dalam penelitian ini

\begin{tabular}{ccc}
\hline \hline Nilai Denda & Nilai Rupiah & Skor \\
\hline Sangat & $0-99.999 .999$ & 1 \\
Ringan & $100.000 .000-$ & 2 \\
Ringan & 199.999 .999 & \\
& $200.000 .000-$ & 3 \\
Sedang & 299.999 .999 & \\
& $300.000 .000-$ & 4 \\
Tinggi & 399.999 .999 & \\
Sangat & $400.000 .000-$ & 5 \\
Tinggi & 500.000 .000 & \\
\hline
\end{tabular}

Sumber: Dikembangkan berdasarkan data penelitian ini

\section{Variabel Moderating-Ukuran Bank}

Ukuran perusahaan umumnya digambarkan besar kecilnya berdasar nilai total aset yang dimiliki. Ukuran bank dalam penelitian ini kemudian didasarkan pada hasil logaritma natural total aset (Makni et al., 2009; Cho et al., 2010; Lanis dan Richardson, 2013) dengan rumus sebagai berikut:

$$
\text { Size }=\text { Ln total aset }
$$

\section{Variabel Moderating-RisikoBank}

Riset ini menggunakanproxy CapitalAsset Ratio dan Loan-to-Asset Ratiosebagai indikator risiko bank. Sebab kedua proksi tersebut telah sering digunakan dalam penilaian kinerja perbankan dalam berbagai riset (Arena, 2008; Önder dan Özyilairim, 2008; Zeidan, 2012). Adapun persamaannya:

Serta

$$
\text { Capital }- \text { Asset Ratio }=\frac{\text { Capital Equity }}{\text { Total Assets }}
$$

$$
\text { Loan }- \text { Asset Ratio }=\frac{\text { Loans }}{\text { Total Assets }}
$$

\section{Analisis Statistik}

Pengujian hipotesis penelitian ini menggunakan metode partially least square analysis, dengan menggunakan software statistik SmartPLS. Pilihan ini dipilih berdasar pendapat Lee et al. (2011) dan Ghozali dan Latan (2015) bahwa partially least square analysis dapat digunakan jika model analisis penelitian rumit, membutuhkan pengujian langsung dan tak langsung diantara variabel penelitian dan juga dapat digunakan jika model penelitian tidak mencapai asumption of the classical linear, sebagaimana penelitian ini.

Lebih lanjut, analisis statistik dengan variabel observed menggunakan software SmartPLS, tidak perlu melakukan pengukuran model (measurement model), sehingga langsung melakukan estimasi model struktural (Ghozali dan Latan, 2015).

\section{ANALISIS DAN PEMBAHASAN \\ Analisis Deskriptif}

Tabel 2

Analisis Deskriptif Data Dalam 4 Tahun (2010-2013)

\begin{tabular}{lccccc}
\hline \hline & $\mathbf{N}$ & Min & Max & Mean & Std. Deviation \\
\hline Nilai Denda (Rp) & 108 & 0 & 500.000 .000 & $23.018 .518,52$ & $75.700 .835,37$ \\
Violation & 108 & 1 & 5 & 1,16 & 0,699 \\
AbnROAij & 108 & $-9,80$ & 3,68 & 0,0000 & 1,90153
\end{tabular}




$\begin{array}{lccccc}\text { AbnROEij } & 108 & -68,40 & 28,26 & 1,3170 & 14,69612 \\ \text { NIM } & 108 & 1,02 & 16,64 & 6,3369 & 3,10812 \\ \text { NPL } & 108 & 0,00 & 24,84 & 2,0531 & 2,91213 \\ \text { BOPO } & 108 & 0,83 & 173,80 & 82,2817 & 19,43837 \\ \text { CAR } & 108 & 9,41 & 45,52 & 17,1063 & 5,98759 \\ \text { LDR } & 108 & 40,22 & 140,72 & 84,0768 & 16,29094 \\ \text { SIZE } & 108 & 13,51 & 20,57 & 16,8231 & 1,45423 \\ \text { Nilai aset total } & 108 & \text { Rp 553.012 } & \text { Rp 733.099.762 } & \text { Rp 54.875.945 } & 117868021.5 \\ \text { (.000.000) } & 108 & 0,00 & 63,67 & 11,2309 & 9,04947 \\ \text { CART } & 108 & 0,05 & 16,48 & 0,8004 & 1,53053 \\ \text { LAR } & 108 & & & & \\ \text { Valid N (listwise) } & & & & & \end{array}$

Sumber: Data diolah, 2017

Berdasarkan tabel 2 tersebut ditemukan fakta empiris nilai denda sebagai hukuman atas pelanggaran peraturan yang bank lakukan bervariasi mulai dari Rp 0,- (sanksi bukan denda) hingga Rp 500.000.000,-. Beberapa bank mendapatkan denda dan hukuman secara bergantian dalam rentang tahun 2010-2013 dengan rata-rata nilai denda yang diberikan sebesar Rp 23.018.518,52. Selanjutnya, dikarenakan penelitian ini menggunakan skala interval untuk mengukur tingkat denda (violation) yang diberikan oleh OJK dengan skala-1-sangat ringan, hingga skala-5-sangat tinggi. Maka dapat dilihat dalam tabel 2, bahwa rentang rata-rata nilai denda yang diberikan oleh OJK adalah sebesar 1,16. Dengan kata lain, dalam tahun 2010-2013 denda yang diberikan masih dalam kategori sangat ringan hingga ringan.

Selanjutnya, untuk variabel kinerja keuangan yang dalam penelitian ini menggunakan dua acuan penilaian. Pertama, proksi kinerja keuangan abnormal yang dikembangkan oleh Zeidan (2012) untuk mengukur nilai abnormal ROA dan ROE dari bank yang melakukan pelanggaran peraturan keuangan ditemukan nilai ratarata untuk Abnormal ROA sebesar $0 \%$ atau secara rata-rata tidak ditemukan perubahan nilai ROA yang abnormal dari data penelitian. Sedangkan, untuk Abnormal ROE memiliki nilai sebesar 1,3\% yang juga menunjukkan fakta bahwa perubahan nilai ROE dalam rentang waktu penelitian tidak begitu signifikan.
Kedua, proksi kinerja keuangan versi Bank Indonesia berdasarkan Peraturan Bank Indonesia Nomor 6/10/PBI/2004 tanggal 12 April 2004 tentang sistem penilaian tingkat kesehatan bank umum dan ukuran kinerja perbankan yang diungkapkan pada Laporan Tahunan Ekonomi Indonesia (BI, 2013). Tabel 2 menunjukkan fakta empiris, nilai NIM yang digunakan untuk mengukur pendapatan bunga bersih dibandingkan dengan aset produktif yang dimiliki perbankan memiliki nilai rata-rata $6,33 \%$ yang menunjukkan kualitas bank-bank pelanggar peraturan keuangan terlihat aman dari sisi pendapatannya. NPL atau rasio yang mengukur kredit bermasalah menunjukkan fakta empiris bahwa bank yang menjadi sampel dalam penelitian ini secara rata-rata memiliki tingkat kredit bermasalah sebesar $2,05 \%$ yang berarti masih dalam taraf aman yakni $<5 \%$ sebagaimana yang diatur oleh BI (2017).

Begitu pula dengan nilai perbandingan beban operasional terhadap pendapatan operasional (BOPO) sebesar 82,28\% yang masih berada dalam standar aman BI $<85 \%$ (KONTAN, 2013; BI, 2015). Nilai CAR yang memiliki makna kemampuan bank untuk mengembangkan kredit rata-rata $17,10 \%$ yang juga masih berada di atas ambang minimun $8 \%$ yang ditentukan BI (2013), juga nilai LDR atau kemampuan untuk membayarkan kredit berbasis simpanan pihak ketiga masih dalam taraf aman $84,07 \%$ dari standar $85-110 \%$ (BI, 2013). 
Selanjutnya, variabel moderasi yang diukur dengan proksi ukuran bank atau SIZE dari nilai logaritma natural total aset bank yang menjadi sampel. Di mana nilai riil rata-rata total Aset bank yang menjadi sampel adalah Rp 54.875.945.000.000,-. Kemudian variabel moderasi lainnya, CART (capitalasset ratio) yang berguna untuk mengetahui nilai perbandingan total modal bank atas total asetnya didapatkan nilai rata-rata $11,23 \%$ yang artinya bank-bank yang menjadi sampel penelitian ini memiliki kekuatan modal yang cukup dalam menjalankan usahanya. Variabel moderasi terakhir, de- ngan proksi LAR (loan-asset ratio) yang menggambarkan kemampuan pembayaran utang dari bank yang menjadi sampel mendapatkan nilai rata-rata $80 \%$ yang berarti bank sampel secara rata-rata memiliki tunggakan utang sebesar $80 \%$ dari total asetnya.

\section{Menilai Model Pengukuran (Outer Model)}

Dalam penelitian yang menggunakan pendekatan PLS dengan format konstruktif. Penilaian model pengukuran dimulai dengan pengujian latent variable correlations sesuai saran Ghozali dan Latan (2015). Sehingga didapatkan hasil tabel 3 berikut:

Tabel 3

Latent Variable Correlations

\begin{tabular}{ccccccccc}
\hline \hline & AbnROAij & AbnROEij & BOPO & CAR & CART & LAR & LDR & NIM \\
\hline AbnROAij & 1.000000 & & & & & & & \\
AbnROEij & 0.811032 & 1.000000 & & & & & & \\
BOPO & -0.695204 & -0.679448 & 1.000000 & & & & & \\
CAR & 0.200562 & -0.080703 & -0.148204 & 1.000000 & & & \\
CART & 0.064893 & 0.162347 & -0.060534 & -0.281010 & 1.000000 & & & \\
LAR & -0.001943 & -0.001056 & -0.002674 & -0.005733 & -0.11861 & 1.000000 & & \\
LDR & 0.304847 & 0.306661 & -0.418277 & -0.014036 & -0.08927 & 0.016527 & 1.000000 & \\
NIM & 0.455031 & 0.400419 & -0.276079 & 0.027563 & -0.08176 & 0.001079 & 0.408039 & 1.000000 \\
NPL & -0.309942 & -0.249550 & 0.330184 & -0.165083 & -0.01797 & 0.013451 & -0.07367 & -0.22728 \\
Violation & -0.045181 & 0.080195 & 0.016942 & -0.033320 & 0.003788 & -0.03960 & 0.010333 & -0.07695 \\
SIZE & 0.238413 & 0.253323 & -0.317253 & -0.250643 & 0.410880 & -0.00191 & 0.276773 & 0.057111 \\
\hline
\end{tabular}

Sumber: Data diolah dengan SmartPLS 2.0 (M3)

Berdasarkan data tabel 3 ditemukan fakta bahwa besaran korelasi antara variabel independen masih berada di bawah 95\% atau $<10$ dari nilai VIF. Hal tersebut bermakna bahwa tidak ditemukan kondisi multikolinearitas yang serius. Sehingga data ini layak untuk diproses lebih lanjut dalam pengujian model struktural.

\section{Menilai Model Struktural (Inner Model)}

Penilaian model struktural dengan PLS, dimulai dengan melihat nilai $R$-Squares untuk setiap variabel sebagai gambaran kekuatan prediksi dari model struktural. Disebabkan penelitian ini menggunakan variabel moderasi, maka uji $R$-Square dilakukan dua tahap yakni sebelum dan sesudah ditambahkannya variabel moderasi dalam persamaan. Berikut tabel $R$-Square penelitian ini yang ditunjukkan dalam tabel 4 :

Tabel 4

Hasil Uji R-Square

\begin{tabular}{ccc}
\hline \hline \multicolumn{2}{c}{$\begin{array}{c}\text { Tanpa Variable } \\
\text { Moderasi }\end{array}$} & $\begin{array}{c}\text { Dengan Variabel } \\
\text { moderasi }\end{array}$ \\
\hline & R Square & R Square \\
AbnROAij & 0.059145 & 0.073941 \\
AbnROEij & 0.077013 & 0.107979 \\
BOPO & 0.100651 & 0.102527 \\
CAR & 0.065095 & 0.065114 \\
CART & - & - \\
LAR & - & - \\
LDR & 0.077287 & 0.077289
\end{tabular}




$\begin{array}{ccc}\text { NIM } & 0.008711 & 0.010325 \\ \text { NPL } & 0.015119 & 0.017498 \\ \text { Violation } & - & - \\ \text { SIZE } & - & -\end{array}$

Sumber: Data diolah dengan SmartPLS 2.0 (M3)

Dari tabel 4 tersebut, ditemukan fakta empiris bahwa nilai $R$-Square yang didapatkan dari model analitis penelitian ini memiliki rentang nilai sebesar 1\%-10,8\%. Hasil tersebut menunjukkan fakta bahwa kemampuan penjelasan tiap variabel yang digunakan dalam penelitian ini rendah, sebab nilainya masih di bawah 0,50 atau $50 \%$ (Ghozali dan Latan, 2015). Namun, hal tersebut dapat dimengerti sebab kajian dengan menggunakan pengukuran yang belum luas digunakan seperti pengukuran denda atas pelanggaran yang diterima oleh bank, belum memiliki proksi acuan khusus yang telah robust di dunia akademik. Sebagaimana yang juga ditemukan oleh peneliti lain (Zeidan, 2012, 2013; Shahib dan Irwandi, 2016).

Selanjutnya, setelah mendapatkan nilai $R$-square, maka berlanjut pada analisis model struktural dengan melihat nilai signifikansi untuk mengetahui pengaruh antar variabel melalui prosedur bootsrapping (Ghozali dan
Latan, 2015; Shahib dan Irwandi, 2016).Pada penelitian ini, nilai signifikansi yang digunakan (two-tailed) t-value adalah di atas 1,96 (significance level $=5 \%$ ) sekaligus sebagai acuan batas untuk mendukung atau tidak mendukung hipotesis yang diajukan. Sehingga, apabila nilai $t$-statistik lebih kecil dari 1,96 maka hipotesis ditolak sedangkan apabila nilai $t$-statistik lebih besar dari 1,96 maka hipotesis didukung. Sama seperti hasil dari $R$-Square, nilai signifikansi juga ditunjukkan dalam dua model persamaan yaitu, persamaan tanpa variabel moderasi dan dengan variabel moderasi, seperti yang ditunjukkan tabel 5 dan 6. Dari tabel 5 dan 6 ditemukan fakta empiris bahwa tidak ditemukan pengaruh yang signifikan atas variabel utama terhadap variabel lain, yang diukur dengan proksi violation, dan digunakan untuk menguji hipotesis pada penelitian ini. Hal ini ditunjukkan dengan nilai signifikansinya yang berada di bawah 1,96 , batas standar statistik untuk didukungnya hipotesis pada metode PLS. Begitu juga dengan variabel-variabel moderator (CART, LAR, SIZE) yang digunakan di penelitian ini yang mendapatkan nilai t-statistik di bawah 1,96 , sehingga membuat variabel dan hipotesis yang terkait dengan variabel moderator tertolak.

Tabel 5

Path coeficients (mean, stdev, t-values) tanpa Variabel Moderasi

\begin{tabular}{|c|c|c|c|c|c|}
\hline & $\begin{array}{c}\text { Original } \\
\text { Sample (O) }\end{array}$ & $\begin{array}{c}\text { Sample Mean } \\
\text { (M) }\end{array}$ & $\begin{array}{l}\text { Standard } \\
\text { Deviation } \\
\text { (STDEV) }\end{array}$ & $\begin{array}{c}\text { Standard } \\
\text { Error } \\
\text { (STERR) }\end{array}$ & $\begin{array}{c}\text { T Statistics } \\
\text { (|0/STERR) }\end{array}$ \\
\hline CART $->$ AbnROAij & -0.039820 & -0.064568 & 0.105594 & 0.105594 & 0.377108 \\
\hline CART -> AbnROEij & 0.068627 & 0.064616 & 0.068622 & 0.068622 & 1.000062 \\
\hline LAR -> AbnROAij & -0.007405 & 0.006205 & 0.073459 & 0.073459 & 0.100806 \\
\hline LAR -> AbnROEij & 0.011229 & 0.051240 & 0.087449 & 0.087449 & 0.128406 \\
\hline Violation -> AbnROAij & -0.030907 & -0.030289 & 0.099004 & 0.099004 & 0.312180 \\
\hline Violation -> AbnROEij & 0.093513 & 0.101426 & 0.095445 & 0.095445 & 0.979760 \\
\hline Violation -> ВОРО & -0.001140 & 0.002488 & 0.041495 & 0.041495 & 0.027469 \\
\hline Violation -> CAR & -0.047757 & -0.048879 & 0.044515 & 0.044515 & 1.072840 \\
\hline Violation -> LDR & 0.026189 & 0.028001 & 0.100991 & 0.100991 & 0.259322 \\
\hline
\end{tabular}


96 Ekuitas: Jurnal Ekonomi dan Keuangan - Volume 2, Nomor 1, Maret 2018 : 83 - 105

\begin{tabular}{llllll} 
Violation -> NIM & -0.073939 & -0.073603 & 0.077030 & 0.077030 & 0.959878 \\
Violation -> NPL & -0.050533 & -0.052185 & 0.059380 & 0.059380 & 0.851019 \\
SIZE -> AbnROAij & 0.252999 & 0.252476 & 0.073599 & 0.073599 & $\mathbf{3 . 4 3 7 5 1 4 ^ { * }}$ \\
SIZE -> AbnROEij & 0.230475 & 0.224665 & 0.073086 & 0.073086 & $\mathbf{3 . 1 5 3 4 9 7 ^ { * }}$ \\
SIZE -> BOPO & -0.317318 & -0.321999 & 0.062367 & 0.062367 & $\mathbf{5 . 0 8 7 9 4 3}^{*}$ \\
SIZE -> CAR & -0.253365 & -0.256895 & 0.075586 & 0.075586 & $\mathbf{3 . 3 5 2 0 1 2 ^ { * }}$ \\
SIZE -> LDR & 0.278265 & 0.277826 & 0.097189 & 0.097189 & $\mathbf{2 . 8 6 3 1 3 0 ^ { * }}$ \\
SIZE -> NIM & 0.052898 & 0.051012 & 0.087973 & 0.087973 & 0.601296 \\
SIZE -> NPL & -0.115011 & -0.119230 & 0.064600 & 0.064600 & 1.780351 \\
\hline
\end{tabular}

Sumber: Data diolah dengan SmartPLS 2.0 (M3)

Tabel 6

Path coeficients (mean, stdev, t-values) dengan Variabel Moderasi

\begin{tabular}{|c|c|c|c|c|c|}
\hline & $\begin{array}{c}\text { Original } \\
\text { Sample (O) }\end{array}$ & $\begin{array}{l}\text { Sample Mean } \\
\text { (M) }\end{array}$ & $\begin{array}{l}\text { Standard } \\
\text { Deviation } \\
\text { (STDEV) }\end{array}$ & $\begin{array}{c}\text { Standard } \\
\text { Error (STERR) }\end{array}$ & $\begin{array}{c}\text { TStatistics } \\
(\mid \text { O/STERR } \mid)\end{array}$ \\
\hline CART -> AbnROAij & 4.601742 & 213453740459.81 & 7707642384378.564 & 7707642384378.5 & 0.000000 \\
\hline CART -> AbnROEij & 2.237166 & -34981222592.34 & 3619156395255.279 & 36191563952.27 & 0.000000 \\
\hline LAR $\rightarrow$ AbnROAij & -2.205158 & -37168474169.89 & 1203051914329.370 & 12030519143.37 & 0.000000 \\
\hline LAR -> AbnROEij & -2.594070 & -18174278006.61 & 1074460589189.042 & 1074460589189.0 & 0.000000 \\
\hline Violation -> AbnROAij & 4.260375 & 41691281147.354 & 4887060897829.118 & 4887060897829.1 & 0.000000 \\
\hline Violation -> AbnROEij & 3.684328 & -29361026628.68 & 2166457520619.562 & 2166457520619.5 & 0.000000 \\
\hline Violation -> BOPO & -0.727160 & -0.292569 & 5.298954 & 5.298954 & 0.137227 \\
\hline Violation -> CAR & 0.024084 & -0.960881 & 8.467156 & 8.467156 & 0.002844 \\
\hline Violation -> LDR & 0.049146 & 0.764815 & 4.765636 & 4.765636 & 0.010313 \\
\hline Violation -> NIM & 0.599460 & 0.415453 & 8.257926 & 8.257926 & 0.072592 \\
\hline Violation -> NPL & 0.767104 & 1.308710 & 6.279090 & 6.279090 & 0.122168 \\
\hline $\begin{array}{l}\text { Violation * CART -> } \\
\text { AbnROAij }\end{array}$ & -6.178488 & -197247437584.6 & 8535968998787.955 & 8535968998787.9 & 0.000000 \\
\hline $\begin{array}{l}\text { Violation * CART -> } \\
\text { AbnROEij }\end{array}$ & -2.891623 & 37983542196.956 & 3965551325067.947 & 3965551325067.9 & 0.000000 \\
\hline $\begin{array}{l}\text { Violation * LAR -> } \\
\text { AbnROAij }\end{array}$ & 2.260952 & 34282952805.094 & 2052369006864.508 & 2052369006864.5 & 0.000000 \\
\hline $\begin{array}{l}\text { Violation * LAR -> } \\
\text { AbnROEij }\end{array}$ & 2.675327 & 26326204945.045 & 1603418778350.059 & 1603418778350.0 & 0.000000 \\
\hline $\begin{array}{l}\text { Violation * size -> } \\
\text { AbnROAij }\end{array}$ & -0.743190 & 0.017860 & 46.890073 & 46.890073 & 0.015850 \\
\hline $\begin{array}{l}\text { Violation * size -> } \\
\text { AbnROEij }\end{array}$ & -2.287162 & -1.451915 & 14.177180 & 14.177180 & 0.161327 \\
\hline Violation * size $->$ NIM & -0.675680 & -0.471559 & 8.402691 & 8.402691 & 0.080412 \\
\hline Violation * size $->$ NPL & -0.820408 & -1.373551 & 6.368397 & 6.368397 & 0.128825 \\
\hline Violation * size $->$ BOPO & 0.728480 & 0.292761 & 5.398823 & 5.398823 & 0.134933 \\
\hline
\end{tabular}




\begin{tabular}{llllll} 
Violation * size -> CAR & -0.072085 & 0.935805 & 8.612653 & 8.612653 & 0.008370 \\
Violation * size -> LDR & -0.023034 & -0.745585 & 4.787402 & 4.787402 & 0.004811 \\
size -> AbnROAij & 0.358862 & 0.367388 & 6.720321 & 6.720321 & 0.053399 \\
size -> AbnROEij & 0.529197 & 0.417699 & 1.896486 & 1.896486 & 0.279041 \\
size -> BOPO & -0.417112 & -0.331854 & 1.163502 & 1.163502 & 0.358497 \\
size -> CAR & -0.243490 & -0.441579 & 1.845843 & 1.845843 & 0.131913 \\
size -> LDR & 0.281420 & 0.379209 & 0.814339 & 0.814339 & 0.345582 \\
size -> NIM & 0.145459 & 0.067127 & 1.776629 & 1.776629 & 0.081874 \\
size -> NPL & -0.002623 & 0.102155 & 1.326605 & 1.326605 & 0.001978 \\
\hline
\end{tabular}

Sumber: Data diolah dengan SmartPLS 2.0 (M3)

Namun, menjadi menarik untuk melihat hasil yang ditampilkan oleh tabel 5 yang menunjukkan ukuran bank (SIZE) bank-bank pelanggar peraturan keuangan memiliki pengaruh positif dan signifikan (ditandai dengan "* *) terhadap abnormalitas ROA dan ROE yang sering menjadi ukuran perusahaan dengan masalah pelanggaran peraturan keuangan (Zeidan, 2012, 2013). Selanjutnya, dapat juga disaksikan pada tabel 5, SIZE bank pelanggar peraturan keuangan berpengaruh negatif dan signifikan terhadap BOPO dan CAR. Dan SIZE berpengaruh positif dan signifikan terhadap LDR. Temuan ini menggambarkan bahwa semakin kecil nilai aset bank pelanggar peraturan keuangan cenderung memiliki nilai BOPO dan CAR yang tinggi. Serta, semakin besar nilai aset bank pelanggar peraturan keuangan maka semakin besar pula nilai LDR-nya.

\section{Analisis Tambahan Pengujian Data}

Sebelum masuk ke pembahasan hipotesis, guna meningkatkan kualitas penelitian ini, khususnya guna mendapatkan penjelasan yang lebih komprehensif terhadap hasil uji statistik yang menunjukkan tidak adanya pengaruh variabel violation atau pelanggaran peraturan keuangan yang diukur dengan skor tingkat pelanggaran peraturan keuangan begitu juga dengan tidak adanya pengaruh variabel moderasi yang digunakan dalam penelitian ini. Maka dilakukan uji statistik dengan melakukan transformasi nilai denda pelanggaran peraturan keua- ngan OJK dan BI ke dalam bentuk logaritma natural (ln) sebagaimana yang umumnya dilakukan jika mengalami kendala pengujian statistik (Ghozali, 2011).

Maka berikut analisis statistik dengan menggunakan nilai logaritma natural denda atas pelanggaran peraturan keuangan ( $\mathrm{Ln}$ Violation) dengan menggunakan software SmartPLS, ditampilkan dalam tabel 7 dan 8 . Berdasarkan data tabel 7 ditemukan fakta bahwa besaran korelasi antara variabel independen dalam persamaan yang menggunakan Ln-Violation, sama dengan persamaan utama, yakni masih berada di bawah 95\% atau < 10 dari nilai VIF. Sehingga, hal tersebut bermakna, dalam uji statistik tambahan ini, tidak ditemukan kondisi multikolinearitas yang serius.

Selanjutnya, jika melihat nilai $R$-Square pada tabel 8, yang ditemukan dalam analisis tambahan ini, tidak jauh berbeda dengan analisis sebelumnya yang menemukan fakta bahwa nilai $R$-square untuk masing-masing variabel utama dalam penelitian ini berada dalam rentang 1\%-10\%. Sekali lagi, hasil tersebut menunjukkan fakta bahwa kemampuan penjelasan tiap variabel yang digunakan dalam penelitian ini rendah, sebab nilainya masih di bawah 0,50 atau $50 \%$ (Ghozali dan Latan, 2015). Namun, hal tersebut dapat di mengerti sebab kajian dengan menggunakan pengukuran yang belum luas digunakan seperti pengukuran denda atas pelanggaran yang diterima oleh bank, belum memiliki proxi acuan khusus yang telah robust di dunia akademik. 
Tabel 7

Latent Variable Correlations

\begin{tabular}{|c|c|c|c|c|c|c|c|c|}
\hline & AbnROAij & AbnROEij & BOPO & CAR & CART & LAR & LDR & NIM \\
\hline AbnROAij & 1.000000 & & & & & & & \\
\hline AbnROEij & 0.811032 & 1.000000 & & & & & & \\
\hline BOPO & -0.695204 & -0.679448 & 1.000000 & & & & & \\
\hline CAR & 0.200562 & -0.080703 & -0.148204 & 1.000000 & & & & \\
\hline CART & 0.064893 & 0.162347 & -0.060534 & -0.281010 & 1.000000 & & & \\
\hline LAR & -0.001943 & -0.001056 & -0.002674 & -0.005733 & -0.118616 & 1.000000 & & \\
\hline LDR & 0.304847 & 0.306661 & -0.418277 & -0.014036 & -0.089273 & 0.016527 & 1.000000 & \\
\hline NIM & 0.455031 & 0.400419 & -0.276079 & 0.027563 & -0.081766 & 0.001079 & 0.408039 & 1.00000 \\
\hline NPL & -0.309942 & -0.249550 & 0.330184 & -0.165083 & -0.017974 & 0.013451 & -0.073672 & -0.22728 \\
\hline $\begin{array}{l}\text { Ln- } \\
\text { Violation }\end{array}$ & -0.133808 & -0.055540 & 0.031483 & -0.162590 & 0.018717 & -0.079130 & 0.014079 & -0.13650 \\
\hline SIZE & 0.238413 & 0.253323 & -0.317253 & -0.250643 & 0.410880 & -0.001916 & 0.276773 & 0.05711 \\
\hline
\end{tabular}

Sumber: Data diolah dengan SmartPLS 2.0 (M3)

Tabel 8

Hasil Uji R-Square

\begin{tabular}{ccc}
\hline \hline \multicolumn{2}{c}{$\begin{array}{c}\text { Tanpa Variable } \\
\text { Moderasi }\end{array}$} & $\begin{array}{c}\text { Dengan Variabel } \\
\text { moderasi }\end{array}$ \\
\hline R Square & R Square \\
\hline AbnROAij & 0.078785 & 0.092598 \\
AbnROEij & 0.072510 & 0.075474 \\
BOPO & 0.102516 & 0.102589 \\
CAR & 0.086372 & 0.089825 \\
CART & - & - \\
LAR & - & - \\
LDR & 0.076618 & 0.083281 \\
NIM & 0.022499 & 0.022638 \\
NPL & 0.039900 & 0.043054 \\
Ln- & - & - \\
Violation & - & - \\
SIZE & - & \\
\hline Sumber: Data diolah dengan SmartPLS 2.0 (M3)
\end{tabular}

Sebagaimana yang juga ditemukan oleh peneliti lain (Zeidan, 2012, 2013; Shahib dan Irwandi, 2016). Terdapat hal yang menarik dalam analisis tambahan ini yang berbeda dengan analis sebelumnya. Jika di analisis sebelumnya ditemukan fakta adanya perubahan nilai $t$-statistik sebelum dan sesudah menambahkan variabel moderasi. Dalam analisis tambahan ini hal tersebut tidak berlaku.

Sebaliknya, terdapat konsistensi hasil antara model persamaan yang belum dan yang telah menggunakan variabel moderasi. Sebagaimana ditunjukkan oleh tabel 9 dan 10 yang sama-sama menunjukkan SIZE bank memiliki pengaruh positif dan signifikan (ditandai dengan "* *) terhadap abnormalitas ROA dan ROE.

Selanjutnya, variabel SIZE berpengaruh negatif dan signifikan terhadap BOPO dan CAR serta SIZE juga tetap berpengaruh positif dan signifikan terhadap LDR. 
Tabel 9

Path coeficients (mean, stdev, t-values) tanpa Variabel Moderasi

\begin{tabular}{|c|c|c|c|c|c|}
\hline & $\begin{array}{c}\text { Original } \\
\text { Sample (O) }\end{array}$ & $\begin{array}{c}\text { Sample } \\
\text { Mean (M) }\end{array}$ & $\begin{array}{l}\text { Standard } \\
\text { Deviation } \\
\text { (STDEV) }\end{array}$ & $\begin{array}{c}\text { Standard } \\
\text { Error } \\
\text { (STERR) }\end{array}$ & $\begin{array}{c}\text { T Statistics } \\
(|\mathrm{O} / \mathrm{STERR}|)\end{array}$ \\
\hline CART -> AbnROAij & -0.041683 & -0.059776 & 0.092684 & 0.092684 & 0.449738 \\
\hline CART -> AbnROEij & 0.070747 & 0.071300 & 0.063650 & 0.063650 & 1.111507 \\
\hline LAR -> AbnROAij & -0.017785 & 0.000091 & 0.071637 & 0.071637 & 0.248271 \\
\hline LAR -> AbnROEij & 0.002626 & 0.038822 & 0.081522 & 0.081522 & 0.032208 \\
\hline $\begin{array}{l}\text { Ln-Violation -> } \\
\text { AbnROAij }\end{array}$ & -0.144046 & -0.135022 & 0.102240 & 0.102240 & 1.408909 \\
\hline $\begin{array}{l}\text { Ln-Violation -> } \\
\text { AbnROEij }\end{array}$ & -0.065008 & -0.058823 & 0.104684 & 0.104684 & 0.620993 \\
\hline Ln-Violation -> BOPO & 0.043232 & 0.040367 & 0.107292 & 0.107292 & 0.402936 \\
\hline Ln-Violation -> CAR & -0.153563 & -0.158750 & 0.096128 & 0.096128 & 1.597486 \\
\hline Ln-Violation -> LDR & 0.003885 & 0.008755 & 0.099356 & 0.099356 & 0.039106 \\
\hline Ln-Violation -> NIM & -0.138794 & -0.136630 & 0.095978 & 0.095978 & 1.446106 \\
\hline Ln-Violation -> NPL & 0.165420 & 0.156024 & 0.098092 & 0.098092 & 1.686384 \\
\hline size -> AbnROAij & 0.260813 & 0.266565 & 0.075996 & 0.075996 & $3.431925^{*}$ \\
\hline size -> AbnROEij & 0.226654 & 0.227803 & 0.079132 & 0.079132 & $2.864267^{*}$ \\
\hline size -> BOPO & -0.318846 & -0.328208 & 0.062932 & 0.062932 & $5.066508^{*}$ \\
\hline size -> CAR & -0.244985 & -0.245545 & 0.078110 & 0.078110 & $3.136412 *$ \\
\hline size -> LDR & 0.276629 & 0.272621 & 0.106039 & 0.106039 & $2.608748^{*}$ \\
\hline size -> NIM & 0.062226 & 0.062935 & 0.091925 & 0.091925 & 0.676918 \\
\hline size -> NPL & -0.118227 & -0.124968 & 0.069026 & 0.069026 & 1.712782 \\
\hline
\end{tabular}

Sumber: Data diolah dengan SmartPLS 2.0 (M3)

Tabel 10

Path coeficients (mean, stdev, t-values) dengan Variabel Moderasi

\begin{tabular}{cccccc}
\hline \hline & $\begin{array}{c}\text { Original } \\
\text { Sample (O) }\end{array}$ & $\begin{array}{c}\text { Sample } \\
\text { Mean (M) }\end{array}$ & $\begin{array}{c}\text { Standard } \\
\text { Deviation } \\
\text { (STDEV) }\end{array}$ & $\begin{array}{c}\text { Standard } \\
\text { Error } \\
\text { (STERR) }\end{array}$ & $\begin{array}{c}\text { T Statistics } \\
(\mid \text { O/STERR |) }\end{array}$ \\
\hline CART ->AbnROAij & -0.001723 & -0.063152 & 0.202159 & 0.202159 & 0.008525 \\
CART ->AbnROEij & 0.093841 & 0.099371 & 0.139853 & 0.139853 & 0.671001 \\
LAR ->AbnROAij & -0.007645 & 0.049420 & 0.121748 & 0.121748 & 0.062790 \\
LAR ->AbnROEij & 0.006978 & 0.077675 & 0.127744 & 0.127744 & 0.054624 \\
Ln-Violation ->AbnROAij & 0.271720 & 0.634563 & 1.080611 & 1.080611 & 0.251450 \\
Ln-Violation ->AbnROEij & 0.284618 & 0.475648 & 1.099983 & 1.099983 & 0.258748
\end{tabular}




\begin{tabular}{|c|c|c|c|c|c|}
\hline Ln-Violation -> BOPO & -0.057532 & -0.121791 & 0.992403 & 0.992403 & 0.057973 \\
\hline Ln-Violation -> CAR & -0.844632 & -0.938574 & 1.151866 & 1.151866 & 0.733273 \\
\hline Ln-Violation -> LDR & 0.963851 & 0.919743 & 1.311355 & 1.311355 & 0.735004 \\
\hline Ln-Violation -> NIM & -0.277465 & -0.248868 & 1.033897 & 1.033897 & 0.268368 \\
\hline Ln-Violation -> NPL & 0.825925 & 0.767647 & 0.946545 & 0.946545 & 0.872568 \\
\hline $\begin{array}{c}\text { Ln-Violation * CART - } \\
>\text { AbnROAij }\end{array}$ & -0.116646 & -0.217808 & 0.434163 & 0.434163 & 0.268670 \\
\hline $\begin{array}{l}\text { Ln-Violation * CART - } \\
\text { >AbnROEij }\end{array}$ & -0.069125 & -0.069005 & 0.225916 & 0.225916 & 0.305975 \\
\hline $\begin{array}{c}\text { Ln-Violation * LAR - } \\
>\text { AbnROAij }\end{array}$ & -0.351437 & -0.517566 & 0.429248 & 0.429248 & 0.818729 \\
\hline $\begin{array}{c}\text { Ln-Violation * LAR - } \\
\text { >AbnROEij }\end{array}$ & -0.096772 & -0.317676 & 0.474653 & 0.474653 & 0.203880 \\
\hline $\begin{array}{c}\text { Ln-Violation * size - } \\
\text { >AbnROAij }\end{array}$ & 0.009461 & -0.059775 & 1.005218 & 1.005218 & 0.009412 \\
\hline $\begin{array}{c}\text { Ln-Violation * size - } \\
\text { >AbnROEij }\end{array}$ & -0.206227 & -0.186316 & 1.043302 & 1.043302 & 0.197668 \\
\hline Ln-Violation * size -> NIM & 0.139889 & 0.108951 & 1.016373 & 1.016373 & 0.137636 \\
\hline Ln-Violation * size -> NPL & -0.666307 & -0.623009 & 0.907328 & 0.907328 & 0.734362 \\
\hline Ln-Violation * size -> BOPO & 0.101649 & 0.160026 & 0.998276 & 0.998276 & 0.101825 \\
\hline Ln-Violation * size -> CAR & 0.697140 & 0.787885 & 1.103591 & 1.103591 & 0.631701 \\
\hline Ln-Violation * size -> LDR & -0.968399 & -0.930759 & 1.293035 & 1.293035 & 0.748935 \\
\hline size ->AbnROAij & 0.269042 & 0.263978 & 0.112588 & 0.112588 & $2.389610^{*}$ \\
\hline size ->AbnROEij & 0.244097 & 0.239075 & 0.115084 & 0.115084 & $2.121036^{*}$ \\
\hline size -> BOPO & -0.326067 & -0.339936 & 0.091669 & 0.091669 & $3.557007^{*}$ \\
\hline size $->$ CAR & -0.294511 & -0.300429 & 0.115954 & 0.115954 & $2.539890^{*}$ \\
\hline size -> LDR & 0.345427 & 0.347319 & 0.125742 & 0.125742 & $2.747104^{*}$ \\
\hline size -> NIM & 0.052288 & 0.051253 & 0.124082 & 0.124082 & 0.421395 \\
\hline size $->$ NPL & -0.070891 & -0.081042 & 0.094513 & 0.094513 & 0.750064 \\
\hline
\end{tabular}

Sumber: Data diolah dengan SmartPLS 2.0 (M3)

\section{Pembahasan Hipotesis}

Hipotesis pertama $\left(\mathrm{H}_{1}\right)$ yang menyatakan pelanggaran peraturan perbankan berpengaruh negative terhadap kinerja keuangan bank tidak dapat didukung. Hal tersebut didasarkan pada hasil uji statistik di semua model analisis statistik dalam penelitian ini yang menunjukkan nilai $t$ statistik violation dan Ln-violation berada di bawah nilai 1,96 , nilai standar diterimanya hipotesis. Temuan penelitian ini meski tidak sesuai dengan bangunan teori kepatuhan hokum bisnis (compliance theory) yang me- nyatakan pelaku bisnis harus mematuhi aturan-aturan bisnis demi tercapainya efisiensi pasar dan agar bisnis tersebut mendapatkan legitimasi dari masyarakat umum (Watts dan Zimmerman, 1986; Tyler, 1990; Gray et al., 1995; Deegan, 2007). Jika dilihat darisudut pandang yang berbeda, dengan masih bersandar pada pandangan compliance theory tersebut, temuan ini dapat menjadi acuan untuk melakukan evaluasi lebih lanjut kepada efektifitas peraturan keuangan yang mengikat perbankan di Indonesia. Sebab, jika suatu peraturan sudah tidak memiliki 
efek negatif terhadap hal yang diaturnya, itu berarti ada masalah efektifitas dalam berjalannya aturan tersebut. Sebagaimana yang dikaji oleh Langus dan Motta (2007), Zeidan (2012) dan Shahib dan Irwandi (2016) yang menyarankan dilakukannya pengkajian atau review secara tertib atas efektifitas peraturan yang mengikat perusahaan dan perbankan. Sehingga tujuan dari hadirnya peraturan dapat tercapai dan terimplementasi dengan baik dan efektif. Salah satu hal yang paling utama yang sepertinya dapat menjadi langkah awal pemerintah dan entitas pengawas terkait, seperti BI dan OJK untuk diperhatikan dan evaluasi adalah besaran nilai denda sebagai bentuk hukuman yang masih begitu kecil dibandingkan dengan besaran aset yang dimiliki bank-bank yang melanggar tersebut. Sehingga kurang memiliki efek kejut kepada kinerja perbankan dan efek jera kepada bank-bank pelanggar. Sebagaimana digambarkan oleh temuan empiris di penelitian ini, rata-rata nilaiaset bank yang melanggar sebesar Rp 54.875.945.000.000,-, sedangkan nilai denda tertinggi hanya sebesar Rp 500.000.000,-.

Selanjutnya, hipotesis kedua (H2) yang menyatakan bahwa semakin kecil ukuran bank, maka kinerja keuangannya semakin dipengaruhi oleh tindakan pelanggaran aturan perbankan. Juga tidak terbukti secara statistik dalam penelitian ini sebab indikator moderating yang digunakan dalam penelitian ini mendapatkan nilai t-statistik di bawah 1,96. Meski pun demikian ditemukan fakta empiris menarik, terkaitukuran bank pelanggar peraturan keuanganya itu ukuran bank (SIZE) memiliki pengaruh positif dan signifikan secara langsung terhadap abnormalitas ROA dan ROE yang sering menjadi ukuran perusahaan dengan masalah pelanggaran peraturan keuangan (Zeidan, 2012, 2013). Sehingga hal ini, dapat menjadi acuan untuk pengkajian lebih lanjut baik di ranah penelitian perbankan, terlebih ranah evaluasi atas efektifitas pengawasan pelanggaran peraturan perbankan yang dilakukan oleh BI dan OJK. Tidak menutup kemungkinan penilaian atas nilai abnormal dari
ROA dan ROE dapat menjadi acuan baru, sebagai tanda awal (red flag) terjadinya pelanggaran peraturan perbankan.

Terakhir, hipotesis ketiga $\left(\mathrm{H}_{3}\right)$ yang menyatakan semakin berisiko suatu bank, maka kinerja keuangannya semakin dipengaruhi oleh tindakan pelanggaran aturan perbankan. Juga tertolak dalam penelitian ini sebab indikator moderating yang digunakan dalam penelitian ini mendapatkan nilai tstatistik di bawah 1,96. Salah satu kemungkinan penyebab kondisi ini terjadi yaitu tingginya nilai rata-rata aset bank yang masuk dalam kelompok pelanggar peraturan keuangan sehingga bank tersebut tidak terlalu terpengaruh dengan risiko perbankan (Zeidan, 2012, 2013; Shahib dan Irwandi, 2016). Sebagai bukti empirisnya, nilai aset rata-rata dari bank yang menjadi sampel penelitian ini adalah Rp 54.875.945.000.000,dan nilai proksi risikonya seperti CART (capital-asset ratio) mendapatkan nilai ratarata $11,23 \%$ yang artinya bank-bank yang menjadi sampel penelitian ini memiliki kekuatan modal yang cukup dalam menjalankan usahanya. Begitupun kemampuan pembayaran hutang dari bank yang disimbolkan LAR (loan-asset ratio) mendapatkan nilai ratarata $80 \%$ yang berarti bank sampel secara rata-rata memiliki tunggakan utang sebesar $80 \%$ dari total asetnya yang masih dapat dianggap wajar jika dibandingkan dengan besaran rata-rata aset bank yang menjadi sampel dalam penelitian ini.

\section{SIMPULAN DAN SARAN}

Setelah melakukan penelitian dan mendapatkan hasilnya, Berikut beberapa simpulan yang dapat diambil dari penelitian ini. Pertama, pelanggaran peraturan keuangan perbankan tidak memiliki pengaruh yang signifikan terhadap kinerja keuangan bank di Indonesia. Kedua, proksi SIZE dan abnormal ROA dan ROE yang digunakan dalam penelitian ini memiliki peluang untuk digunakan lebih lanjut sebagai bahan kajian akademis di bidang akuntansi perbankan dan bahan acuan kebijakan oleh BI dan OJK, sehingga saran penelitian ini untuk peng- 
ambil kebijakan dalam hal ini BI dan OJK: Pertama, diharapkan melakukan peninjauan dan penilaian kembali atas efektifitas pengawasan tindakan pelanggaran peraturan keuangan perbankan di Indonesia. Kedua, proksi SIZE dan abnormal ROA dan ROE yang digunakan dalam penelitian ini memiliki peluang untuk digunakan lebih lanjut sebagai bahan acuan kebijakan oleh BI dan OJK, guna dapat memberikan indikasi awal (red flag) dari bank-bank yang melanggar peraturan keuangan perbankan. Sebagaimana hasil penelitian ini yang menunjukkan bahwa ukuran bank-bank yang melanggar cenderung mempengaruhi secara positif nilai abnormalitas ROA dan ROE bank-bank pelanggar peraturan keuangan tersebut.

Sedangkan saran untuk penelitian selanjutnya. Pertama, diharapkan, penelitian ke depan sebaiknya menguji pelanggaran peraturan keuangan dengan proksi yang terbaru seperti logaritma natural aset perusahaaan, yang juga digunakan dalam penelitian ini, atau mengembangkan proksi baru yang lebih mampu melihat efek riil dari pelanggaran peraturan keuangan. Kedua, penelitian selanjutnya sebaiknya dapat meneliti secara bersama-sama industri keuangan dan non keuangan yang terdaftar diBEI. Sehingga dapat ditemukan penjelasan yang lebih kompleks terkait kasus pelanggaran peraturan keuangan yang dilakukan perusahaan dalam konteks di Indonesia. Ketiga, penelitian ke depan juga sebaiknya dapat mengubah fokus penelitian ini menjadi lebih spesifik, seperti dapat langsung meneliti bagaimana seorang manajer terlibat dalam proses pembangkangan hukum yang dapat berujung denda dan rusaknya kinerja perusahaan.

\section{DAFTAR PUSTAKA}

Adeyemo Kingsley, A. 2012. Frauds in Nigerian Banks: Nature, Deep-Seated Causes, Aftermaths and Probable Remedies. Mediterranean Journal of Social Sciences 3(2): 279-289.

Alexander, K. 2006. Corporate Governance and Banks: The Role of Regulation in
Reducing the Principal-Agent Problem. Journal of Banking Regulation 7(1-2): 1740.

Arena, M. 2008. Bank Failures and Bank Fundamentals: A Comparative Analysis of Latin America and East Asia During the Nineties Using Bank-Level Data. Journal of Banking and Finance 32(2): 299310.

Arjoon, S. 2005. Corporate Governance: An Ethical Perspective. Journal of Business Ethics 61(4): 343-352.

Ball, R. 2009. Market and Political/Regulatory Perspectives on the Recent Accounting Scandals. Journal of Accounting Research 47(2): 277-323.

Barth, J. R., G. Caprio, dan R. Levine. 2004. Bank Regulation and Supervision: What Works Best?. Journal of Financial Intermediation 13(2): 205-248.

Barth, J. R., G. Caprio, dan R. Levine. 2008. Bank Regulations are Changing: for Better or Worse?. Comparative Economic Studies 50(4): 537-563.

Baucus, M. S. dan D. A. Baucus. 1997. Paying The Piper: An Emperical Examination of Longer-Term Financial Consequences of Illegal Corporate Behavior. Academy of Management Journal 40(1): 129-151.

Benmelech, E., dan T. J. Moskowitz. 2010. The Political Economy of Financial Regulation: Evidence from US State Usury Laws in the 19th Century. The Journal of Finance 65(3): 1029-1073.

Bank Indonesia. 2012. Laporan Perekonomian Indonesia 2012.

- - - . 2013. Laporan Perekonomian Indonesia 2013.

- - - 2015. Laporan Perekonomian Indonesia 2015.

- - . 2017. Stabilitas Sistem Keuangan. http://www.bi.go.id/id/peraturan/ssk/Pages/ pbi_171115.aspx. Diakses tanggal 5 September 2017.

Blacconiere, W. G. dan D. M. Patten. 1994. Environmental Disclosures, Regulatory Costs, and Changes in Firm Value. Journal of Accounting and Economics 18(3): 357-377. 
Black, B. 2008. Should the SEC Be a Collection Agency for Defrauded Investors?. The Business Lawyer 63(2): 317-346.

Carson, T. L. 2003. Self-Interest and Business Ethics: Some Lessons of the Recent Corporate Scandals. Journal of Business Ethics 43(4): 389-394.

Chen, Q., T. Hemmer, dan Y. Zhang. 2007. On the Relation between Conservatism in Accounting Standards and Incentives for Earnings Management. Journal of Accounting Research 45(3): 541-565.

Cho, C. H., R. W. Roberts, dan D. M. Patten. 2010. The Language of US Corporate Environmental Disclosure. Accounting, Organizations and Society 35(4): 431-443.

Christensen, H. B., L. Hail, dan C. Leuz. 2016. Capital-Market Effects of Securities Regulation: Prior Conditions, Implementation, and Enforcement. The Review of Financial Studies 29(11): 2885-2924.

Chung, R., M. Firth, dan J.B. Kim. 2002. Institutional Monitoring and Opportunistic Earnings Management. Journal of Corporate Finance 8(1): 29-48.

Coates IV, J. C. 2015. Towards better CostBenefit Analysis: an Essay on Regulatory Management. Law and Contemporary Problems 78(3): 1-23.

Deegan, C. 2007. Financial Accounting Theory. McGraw-Hill Irwin.Australia.

Dowling, J. M. dan C. F. Yap. 2008. Indonesian Economic Development: Mirage or Miracle?. Journal of Asian Economics 19(5): 474-485.

Firth, M., P. L. Mo, dan R. M. Wong. 2005. Financial Statement Frauds and Auditor Sanctions: An Analysis of Enforcement Actions in China. Journal of Business Ethics 62(4): 367-381.

Fligstein, N. 1996. Markets as Politics: A Political-Cultural Approach to Market Institutions. American Sociological Review 61(4): 656-673.

Ghozali, I. 2011. Analisis Statistik dengan SPSS 19. Undip Press. Semarang.

Ghozali, I., dan H. Latan. 2015. Partial Least Squares, Konsep, Teknik dan Aplikasi Menggunakan Program Smartpls 3.0
Untuk Penelitian Empiris. Badan Penerbit UNDIP. Semarang.

Gray, R., R. Kouhy, dan S. Lavers. 1995. Corporate Social and Enviromental Reporting: a Review of The Literature and a Longitudinal Study of UK Disclosure. Accounting, Auditing, and Accountability Journal 8(2): 47-77.

Gunningham, N. dan J. Rees. 1997. Industry Self-Regulation: an Institutional Perspective. Law \& Policy 19(4): 363-414.

Gunthorpe, D. L. 1997. Business Ethics: a Quantitative Analysis of the Impact of Unethical Behaviour by Publicly Trade Corporations. Journal of Business Ethics 16(5): 537-543.

Hart, O. 2009. Regulation and SarbanesOxley. Journal of Accounting Research 47(2): 437-445.

Hendry, J. 2005. Beyond Self-Interest: Agency Theory and the Board in a Satisficing World. British Journal of Management 16(s1): S55-S63.

Hill, H. 2007. The Indonesian Economy: Growth, Crisis and Recovery. The Singapore Economic Review 52(02): 137166.

Hill, H. dan T. Shiraishi. 2007. Indonesia after the Asian Crisis. Asian Economic Policy Review 2(1): 123-141.

Ikatan Akuntan Indonesia. 2013. Standar Akuntansi Keuangan. Ikatan Akuntan Indonesia. Jakarta.

Jackson, W. D., M. Jickling, G. Shorter, M. Murphy, dan M. Seitzinger. 2006. Banking and Securities Regulation and Agency Enforcement Authorities. CRS Report for Congress, Congressional Research Service.

Kim, J. B., Y. Li, dan L. Zhang. 2011. Corporate Tax Avoidance and Stock Price Crash Risk: Firm-level Analysis. Journal of Financial Economics 100(3): 639662.

KONTAN. 2013. Kejar Efisiensi, BI Batasi BOPO Maksimal 85\%. http://keuangan. kontan.co.id/news/kejar-efisiensi-bi-batasibopo-maksimal-85. Diakses tanggal 1 September 2017. 
Koppell, J. G. 2008. Global Governance Organizations: Legitimacy and Authority in Conflict. Journal of Public Administration Research and Theory 18(2): 177-203.

Lamin, A. dan S. Zaheer. 2012. Wall Street vs Main Street: Firm Strategies for Defending Legitimacy and Their Impact on Different Stakeholders. Organization Science 23(1): 47-66.

Langus, G. dan M. Motta. 2007. The Effect of EU Antitrust Investigations and Fines on The Firm's Valuation.CEPR Discussion Paper No. DP6176.

Lanis, R. dan G. Richardson. 2013. Corporate Social Responsibility and Tax Aggresiveness: a Test of Legitimacy Theory. Accounting, Auditing, and Accountability Journal 26(1): 75-100.

Lee, L., S. Petter, D. Fayard, dan S. Robinson. 2011. On the Use of Partial Least Squares Path Modeling in Accounting Research. International Journal of Accounting Information Systems 12(4): 305-328.

MacLean, T. L. dan M. Behnam. 2010. The Dangers of Decoupling: The Relationship between Compliance Programs, Legitimacy Perceptions, and Institutionalized Misconduct. Academy of Management Journal 53(6): 1499-1520.

Makni, R., C. Francoeur, dan F. Bellavance. 2009. Causality between Corporate Social Performance and Financial Performance: Evidence from Canadian Firms. Journal of Business Ethics 89(3): 409-422.

Mishina, Y., B. J. Dykes, E. S. Block, dan T. G. Pollock. 2010. Why "Good" Firms Do Bad Things: The Effects of High Aspirations, High Expectations, and Prominence on the Incidence of Corporate Illegality. Academy of Management Journal 53(4): 701-722.

Önder, Z. dan S. Özyildirim. 2008. Market Reaction to Risky Banks: did Generous Deposit Guarantee Change It?. World Development 36(8): 1415-1435.
Palepu, Healy, dan Bernard. 2010. Business Analysis and Valuation Using Financial Statement. Thomson.New York.

Parker, C. dan V. Nielsen. 2009.The Challenge of Empirical Research on Business Compliance in Regulatory Capitalism. Annual Review of Law and Social Science 5(1): 45-70.

Patten, D. M. 1991. Exposure, Legitimacy, and Social Disclosure. Journal of Accounting and Public Policy 10(4): 297-308.

Peasnell, K. V., P. F. Pope, dan S. Young. 2005. Board Monitoring and Earnings Management: Do Outside Directors Influence Abnormal Accruals?. Journal of Business Finance and Accounting 32(7-8): 1311-1346.

Posner, E. A. 2001. Controlling Agencies with Cost-Benefit Analysis: A Positive Political Theory Perspective. The University of Chicago Law Review 68(4): 11371199.

Qiang, X. 2007. The Effects of Contracting, Litigation, Regulation, and Tax Costs on Conditional and Unconditional Conservatism: Cross-Sectional Evidence at the Firm Level. TheAccounting Review 82(3): 759-796.

Rezaee, Z. dan R. Riley. 2010. Financial Statement Fraud-Prevention and Detection. John Wiley and Sons, Inc. New Jersey.

Rivard, R. J. dan C. R. Thomas. 1997. The Effect of Interstate Banking on Large Bank Holding Company Profitability and Risk. Journal of Economics and Business 49(1): 61-76.

Robin, D. 2009. Toward an Applied Meaning for Ethics in Business. Journal of Business Ethics 89(1): 139-150.

Salehi, M. dan Z. Azary. 2009. Fraud Detection and Audit Expectation Gap: Empirical Evidence from Iranian Bankers. International Journal of Business and Management 3(10): 65-77.

Schnatterly, K. 2003. Increasing Firm Value Through Detection and Prevention of White-collar Crime. Strategic Management Journal 24(7): 587-614. 
Shahib, H. M. dan S. A. Irwandi. 2016. Violation Regulation of Financial Services Authority (FSA), Financial Performance, and Corporate Social Responsibility Disclosure. Journal of Economics, Business, and Accountancy Ventura 19(1): 141-154.

Shapiro, S. P. 2005. Agency Theory. Annual Review of Sociology 31(1): 263-284.

Shleifer, A. 2005. Understanding Regulation. European Financial Management 11(4): 439-451.

Simpson, W. G. dan T. Kohers. 2002. The Link between Corporate Social and Financial Performance: Evidence from the Banking Industry. Journal of Business Ethics 35(2): 97-109.

Sutinen dan K. Kuperan. 1999. A SocioEconomic Theory of Regulatory Compliance. International Journal of Social Economics 26(1/2/3): 174-193.

Tyler, T. 1990. Why People Obey the Law. Yale University Press.New Haven and London.
Warfield, T. D., J. J. Wild, dan K. L. Wild. 1995. Managerial Ownership, Accounting Choices, and Informativeness of Earnings. Journal of Accounting and Economics 20(1): 61-91.

Watts, R. dan J. L. Zimmerman. 1986. Positive Accounting Theory. Prentice Pp.l Inc.

Watts, R. L. dan J. L. Zimmerman. 1990. Positive Accounting Theory: a Ten Year Perspective. The Accounting Review65(1): 131-156.

Williams, D. F. 2007. Tax and Corporate Responsibility. KPMG.London.

Zeidan, M. J. 2012. The Effects of Violating Banking Regulations on The Financial Performance of The US Banking Industry. Journal of Financial Regulation and Compliance 20(1): 56-71.

Zeidan, M. J. 2013. Effects of Illegal Behavior on the Financial Performance of US Banking Institutions. Journal of Business Ethics 112(2): 313-324. 